\title{
PENGARUH LEVERAGE OPERASI DAN LEVERAGE KEUANGAN TERHADAP LABA PER LEMBAR SAHAM PADA PERUSAHAAN GO PUBLIC
}

\author{
Muhammad Yunus \\ Sekolah Tinggi IImu Ekonomi Makassar (STIEM BONGAYA) \\ yunusmuh008@gmail.com
}

\begin{abstract}
ABSTRAK
Penelitian ini bertujuan untuk mengetahui pengaruh variabel Leverage Operasi dan Leverage Keuangan secara parsial dan simultan terhadap laba per lembar saham. Data yang digunakan dalam penelitian adalah data sekunder yang diperoleh dari BEI yaitu laporan keuangan dari tahun 20152018. Populasi dalam penelitian ini adalah seluruh laporan keuangan perusahaan Go Public Sub Sektor Makanan dan Minuman yang terdaftar di Bursa Efek Indonesia yang sejumlah 26 perusahaan. Teknik pemilihan sampel menggunakan metode purposive sampling dan diperoleh 13 perusahaan. Teknik analisis data yang digunakan adalah analisis regresi linier berganda. Hasil yang di peroleh dalam penelitian ini adalah secara parsial Leverage Operasi (DOL) berpengaruh positif dan signifikan terhadap laba per lembar saham $(E P S)$ dengan nilai nilai $t_{\text {hitung }}<t_{\text {tabel }}(2.630>-1.690)$ dan nilai signifikan lebih kecil $0.05(0.013<0.05)$. Sedangkan variabel Leverage Keuangan (DFL) berpengaruh secara negatif dan tidak signifikan terhadap laba per lembar saham $(E P S)$ dengan nilai $t_{\text {hitung }}>t_{\text {tabel }}(-1.892>-1.690)$ dan nilai signifikansi lebih besar dari 0,05 (0.067>0.05). Kemudian secara simultan Leverage Operasi (DOL) dan Leverage Keuangan (DFL) berpengaruh positif dan signifikan terhadap laba per lembar saham (EPS) dengan nilai $F_{\text {hitung }}>F_{\text {tabel }}(4.389>0.051)$ dengan nilai signifikansi lebih kecil dari $0.05(0.020<0.05)$.
\end{abstract}

Keywords: Leverage operasi, Leverage keuangan dan Laba per lembar saham

\section{PENDAHULUAN}

\section{Latar Belakang}

Laba Per Lembar Saham sangat penting untuk diperhitungkan bagi investor yang akan menginvestasikan dananya dalam bentuk saham. Perhitungan Laba Per Lembar Saham dapat digunakan sebagai alat ukur untuk mengevaluasi prospek sebuah saham. Semakin besar jumlah saham beredar peluang untuk meraup Laba Per Lembar Saham juga akan besar, sebaliknya semakin kecil jumlah saham yang beredar maka peluang untuk 
meraup Laba Per Lembar Saham juga akan kecil.

Menurut Brigham dan Houston (2014), "penggunaan hutang akan mengakibatkan perubahan laba per lembar saham, dan juga mengakibatkan perubahan harga saham perusahaan". Hutang yang digunakan oleh perusahaan dalam memenuhi kebutuhan modal dapat mempengaruhi keuntungan per lembar saham bagi pemilik suatu perusahaan dan juga berpengaruh terhadap harga saham perusahaan. Hutang tersebut bisa berupa hutang operasi (operating leverage) dan hutang keuangan (financial leverage).

Objek dalam penelitian ini yaitu perusahaan Go Public Sub Sektor Makanan dan Minuman yang terdaftar di Bursa Efek Indonesia. Industri Makanan dan Minuman masih menjadi andalan untuk mendongkrak pertumbuhan ekonomi nasional. Industri Makanan dan Minuman berpotensi besar untuk tumbuh karena didukung oleh sumber daya alam yang berlimpah dan permintaan domestik yang besar (Annisa Sulistyo Rini, 2018).

Objek penelitian ini saya lakukan karena sektor makanan dan minuman akan paling tahan terhadap krisis dibandingkan dengan sektor lainnya, karena dalam kondisi krisis maupun tidak produk makanan dan minuman tetap dibutuhkan. Sebab produk ini menjadi kebutuhan pokok bagi masyarakat seluruh Indonesia.

Beberapa penelitian tentang Laba Per Lembar Saham, Chelmi (2012) dalam penelitianya menyatakan bahwa variabel Debt to Total Asset Ratio (DAR), Debt to Equity Ratio (DER) dan Long Term Debt to Equity Ratio (LDER) tidak berpengaruh signifikan baik secara parsial maupun secara simultan terhadap Earnings Per Share (EPS) pada perusahaan properti dan real estate di Bursa Efek Indonesia periode 2008-2011. Temuan berbeda dikemukakan oleh Putra (2013) dalam penelitiannya menyatakan bahwa secara simultan Operating Leverage dan Financial Leverage berpengaruh positif terhadap Earnings Per Share. Secara parsial operating leverage tidak bepengaruh terhadap earnings per share. Financial leverage berpengaruh terhadap Earnings Per Share. 
Tabel 1. Laporan Keuangan yang terdaftar di Bursa Efek Indonesia

\begin{tabular}{|c|c|c|c|c|c|}
\hline NO. & Tahun & Nama & DOL & DFL & EPS \\
\hline 1. & & MYOR & 15.44 & 0.08 & 1.364 .15 \\
\hline 2. & 2015 & CEKA & 4,46 & 0,25 & 358,15 \\
\hline 3. & & DLTA & 107,31 & 4,75 & $11.895,11$ \\
\hline 4. & & MYOR & 13.72 & 0.00 & 60.60 \\
\hline 5. & 2016 & CEKA & 7,76 & 0,14 & 419,66 \\
\hline 6. & & DLTA & 139,71 & 0,09 & 316,90 \\
\hline
\end{tabular}

Sumber : Laporan Keuangan BEl, data diolah (2019)

Berdasarkan tabel 1 tersebut, dapat dijelaskan bahwa Leverage Operasi, Leverage Keuangan dan Laba Per Lembar Saham pada Perusahaan Go Public Sektor Makanan dan Minuman yang terdaftar di Bursa Efek Indonesia mengalami fluktuasi (naik turun) yaitu pada jumlah Degree Of Operating Leverage di perusahaan Mayora Indah Tbk. tahun 2015 sebesar $15,44 \%$ dan pada tahun 2016 sebesar 13,72\% berdasarkan data tersebut maka ditunjukkan adanya penurunan pada total DOL tersebut. Kondisi yang berbeda ditemukan mengalami peningkatan pada perusahaan Wilmar Cahaya Indonesia Tbk. jumlah Degree Of Operating Leverage di tahun 2015 sebesar $4,46 \%$ dan pada tahun 2016 sebesar $7,76 \%$.

Kondisi yang sama ditemukan pada jumlah Degree Of Operating Leverage di perusahaan Delta Djakarta Tbk. pada tahun 2015 sebesar 107,31\% dan tahun 2016 sebesar 158,93\% dari data tersebut menunjukkan adanya peningkatan. Sedangkan kondisi yang berbeda di temukan pada perusahaan Mayora Indah Tbk. dengan jumlah Degree of Financial Leverage di tahun 2015 sebesar $0.08 \%$ dan pada tahun 2016 sebesar $0.00 \%$ sehingga dari data tersebut menunjukkan adanya penurunan. Kondisi yang sama ditemukan pada perusahaan Wilmar Cahaya Indonesia Tbk. jumlah Degree of Financial Leverage pada tahun 2015 sebesar 0,25 \% dan pada tahun 2016 sebesar $0,14 \%$ menunjukkan adanya penurunan. Pada perusahaan Delta Djakarta Tbk. pada tahun 2015 sebesar 4,75\% dan tahun 2016 sebesar 0,09\% juga mengalami penurunan pada Degree of Financial Leverage. Dan kondisi yang sama perusahaan Mayora Indah Tbk. di tahun 2015 sebesar $1.364 .15 \%$ dan tahun 2016 sebesar $60.60 \%$ dari data tersebut menunjukkan adanya penurunan pada jumlah Earnings Per Share. Dan 
kondisi yang berbeda ditemukan pada perusahaan Wilmar Cahaya Indonesia Tbk. jumlah Earnings Per Share di tahun 2015 sebesar 358,15\% dan pada tahun 2016 sebesar 419,66\% sehingga dari data tersebut menunjukkan adanya peningkatan. Kondisi yang berbeda ditemukan adanya penurunan pada jumlah Earnings Per Share di perusahaan Delta Djakarta Tbk. pada tahun 2015 sebesar 11.895,11\% dan tahun 2016 sebesar 316,90\%. Perubahan yang menunjukkan terjadinya fluktuasi menjadi alasan dilakukannya peneltian tersebut.

\section{Tujuan Penelitian}

a. Untuk mengetahui pengaruh Leverage Operasi dan Leverage Keuangan terhadap Laba Per Lembar Saham secara parsial pada perusahaan Go Public Sub Sektor Makanan dan Minuman yang terdaftar di Bursa Efek Indonesia.

b. Untuk mengetahui pengaruh Leverage Operasi dan Leverage Keuangan terhadap Laba Per Lembar Saham secara simultan pada perusahaan Go Public Sub Sektor Makanan dan Minuman yang terdaftar di Bursa Efek Indonesia.

\section{TINJAUAN PUSTAKA}

\section{Leverage}

Hadirnya leverage dalam struktur modal sebuah perusahaan menandakan perusahaan tersebut menghimpun pendanaan dari luar perusahaan dengan harapan untuk meningkatkan laba perusahaan kedepannya.

Menurut Agus Sartono (2010:257) leverage adalah penggunaan assets dan sumber dana (sources of funds) oleh perusahaan yang memiliki biaya tetap (beban tetap) dengan maksud agar meningkatkan keuntungan potensial pemegang saham. Sedangkan menurut Irham Fahmi (2013:174) Leverage merupakan gambaran kemampuan suatu perusahaan dalam memenuhi dan menjaga kemampuannya untuk selalu mampu memenuhi kewajibannya dalam membayar utang secara tepat waktu.

\section{Leverage Operasi}

Leverage operasi menurut Irawati (2006) : Dalam Fauziah (2015), yaitu 
penggunaan aktiva dengan biaya tetap yang bertujuan untuk menghasilkan pendapatan yang cukup untuk menutup biaya tetap dan variabel serta dapat meningkatkan profitabilitas. Teori tersebut menjelaskan bahwa leverage operasi adalah suatu penggunaan aktiva yang menimbulkan beban tetap operasional. Beban tetap operasional biasanya berasal dari biaya depresiasi, biaya produksi serta pemasaran yang bersifat tetap (misalnya gaji bulanan karyawan). Sebagai kebalikannya adalah beban (biaya) variabel operasional.

Adapun kegunaan dari leverage operasi yaitu untuk mengukur perubahan pendapatan atau penjualan terhadap keuntungan operasi perusahaan. Leverage operasi sebagai alat untuk mengukur perubahan laba operasi sebagai akibat perubahan penjualan, sehingga perusahaan dapat mengetahui keuntungan operasi perusahaan.

Operating leverage dapat diukur dengan menggunakan Degree Of Operating Leverage (DOL). DOL merupakan kemampuan Earning Before Interest and Taxes (EBIT) suatu perusahaan dalam merespon fluktuasi penjualan (Utari et al., 2014:265).

\section{Leverage Keuangan}

Leverage keuangan menurut Sartono (2010 : 38) merupakan penggunaan sumber dana yang memiliki beban tetap dengan harapan bahwa penggunaan sumber dana tersebut akan memberikan tambahan keuntungan yang lebih besar daripada beban tetapnya sehingga akan meningkatkan keuntungan yang tersedia bagi pemegang saham.

Menurut Utari et al. (2014:268) jika bunga rendah maka tingkat leverage keuangan juga akan rendah dan jika bunga tinggi maka, tingkat leverage keuangan juga akan tinggi.

Financial leverage dapat diukur dengan menggunakan Degree of Financial Leverage (DFL). Degree of Financial Leverage (DFL) merupakan ukuran kuantitatif sensitivitas EPS suatu perusahaan terhadap perubahan laba operasional (Horne dan Wachowicz,2007:200) : Dalam AW Hardiyanto (2015).

\section{Laba Per Lembar Saham}

Laba per lembar saham atau earning per share merupakan salah satu indikator rasio perusahaan yang penting. Laba per lembar saham adalah 
tingkat keuntungan bersih untuk tiap lembar sahamnya yang mampu diraih perusahaan pada saat menjalankan operasinya.

Laba Per Lembar Saham menurut Darmadji \& Fakhrudin (2012:154) mendefinisikan Laba Per Lembar Saham adalah rasio yang mencerminkan kemampuan perusahaan dalam menghasilkan laba untuk setiap lembar saham yang beredar. Sedangkan menurut Kasmir (2013:207), mendefinisikan Laba Per Lembar Saham adalah rasio laba per lembar saham atau disebut juga rasio nilai buku, merupakan rasio untuk mengukur keberhasilan manajemen dalam mencapai keuntungan bagi pemegang saham.

a. Kegunaan Laba Per Lembar Saham

1) Seorang investor membeli dan mempertahankan saham suatu perusahaan dengan harapan akan memperoleh dividend atau capital gain.

2) Laba per lembar saham diperoleh dari laba yang tersedia bagi pemegang saham biasa dibagi dengan rata-rata saham biasa yang beredar.

3) Jumlah pendapatan yang tersedia bagi pemegang saham adalah pendapatan bersih setelah dikurangi pajak pendapatan.

4) Pendapatan per saham perusahaan biasanya menjadi perhatian pemegang saham pada umumnya atau calon pemegang saham dan manajemen

b. Faktor Yang Mempengaruhi Laba Per Lembar Saham

1) Penggunaan utang

2) Laba bersih debelum bunga dan pajak (EBIT)

c. Faktor-faktor yang menyebabkan kenaikan laba per lembar saham

1) Laba bersih naik dan jumlah saham biasa yang beredar tetap.

2) Laba bersih tetap dan jumlah lembar saham biasa yang beredar turun.

3) Laba bersih naik dan jumlah lembar saham biasa yang beredar turun.

4) Persentase kenaikan laba bersih lebih besar daripada persentase kenaikan jumlah lembar saham biasa yang beredar.

5) Persentase penurunan jumlah lembar saham biasa yang beredar 
lebih besar daripada persentase penurunan laba bersih.

d. Faktor-faktor yang menyebabkan penurunan laba per lembar saham

1) Laba bersih tetap dan jumlah lembar saham biasa yang beredar naik.

2) Laba bersih turun dan jumlah lembar saham biasa yang beredar tetap.

3) Laba bersih turun dan jumlah lembar saham biasa yang beredar naik.

4) Persentase penurunan laba bersih lebih besar daripada persentase penurunan jumlah lembar saham biasa yang beredar.

5) Persentase kenaikan jumlah lembar saham biasa yang bersedar lebih besar daripada persentase kenaikan laba bersih.

e. Pengukuran Laba Per Lembar Saham

Laba Per Lembar Saham menunjukkan kemampuan perusahaan dalam memperoleh laba. Laba Per Lembar Saham dapat dijadikan sebagai indikator tingkat nilai suatu perusahaan. Laba Per Lembar Saham juga merupakan salah satu cara untuk mengukur keberhasilan dalam mencapai sebuah keuntungan bagi para pemilik saham dalam suatu perusahaan.

\section{Pengaruh Leverage Operasi Terhadap Laba Per Lembar Saham}

Leverage operasi adalah penggunaan aktiva dengan biaya tetap yang bertujuan untuk menutup biaya tetap dan biaya variabel serta dapat meningkatkatkan profitabilitas. Leverage operasi terjadi pada saat perusahaan menggunakan aktiva yang akan menimbulkan biaya atau beban tetap. Artinya semakin tinggi efektifitas suatu perusahaan menggunakan aktiva untuk menghasilkan penjualan maka akan meningkatkan keuntungan untuk perusahaan. Tingkat aktivitas operasi perusahaan bergantung pada jumlah asset produktif yang dimiliki perusahaan, dan semakin banyak asset produktif yang dimiliki perusahaan, maka tentu saja aktivitas operasi akan meningkat dan pada akhirnya akan meningkatkan pendapatan bagi suatu perusahaan, serta laba per lembar sahamnya bagi pemegang saham.

\section{Pengaruh Leverage Keuangan Terhadap Laba Per Lembar Saham}

Leverage keuangan adalah suatu ukuran yang menunjukkan sampai sejauh mana hutang dan saham preferen digunakan dalam struktur modal 
perusahaan. Leverage keuangan terjadi akibat penggunaan sumber dana yang berasal dari hutang, sehingga menyebabkan perusahaan harus menanggung hutang serta biaya bunga. Penggunaan hutang yang tinggi atau rendah dapat mempengaruhi naik turunnya keuntungan per lembar saham. Harapannya dengan menggunakan dana tersebut, perusahaan dapat memperoleh pendapatan yang lebih besar daripada beban bunga yang dibayarkan. Artinya dengan pendapatan yang besar tersebut tingkat penghasilan pemilik perusahaan juga akan besar.

Pengaruh Leverage Operasi dan Leverage Keuangan Terhadap Laba Per Lembar Saham

Nilai Degree Of Operating Leverage (DOL) yang merupakan hasil dari perhitungan Operating Leverage meningkat, hal tersebut berarti bahwa tingkat DOL perusahaan semakin besar, maka semakin besar fluktuasi laba terhadap perubahan volume penjualan. Semakin tinggi operating leverage perusahaan, maka semakin tinggi pula sensitivitas EBIT terhadap tingkat penjualan.

Degree Of Financial Leverage (DFL) yang merupakan hasil dari perhitungan analisis financial leverage meningkat, hal tersebut berarti bahwa DFL tersebut mempunyai daya ungkit yang tinggi untuk menghasilkan laba per lembar saham yang tinggi pula. Dan apabila laba per lembar saham naik, maka akan juga meningkatkan laba yang tersedia untuk para pemegang saham. Demikian juga sebaliknya, jika DFL menurun maka daya ungkit untuk menghasilkan laba per lembar saham juga akan ikut turun. Hal tersebut berarti laba yang tersedia untuk para pemegang saham mengalami penurunan.

\section{METODE PENELITIAN}

\section{Tempat Penelitian}

Penelitian ini dilakukan di Galeri Investasi Bursa Efek di Kampus STIEM BONGAYA yang beralamat di jalan Letjend, Andi Mappaoddang No.28 Makassar.

\section{Populasi dan Sampel}

Populasi dalam penelitian ini adalah seluruh laporan keuangan 
perusahaan Go Public Sub Sektor Makanan dan Minuman yang terdaftar di Bursa Efek Indonesia yang berjumlah sebanyak 26 perusahaan. Sampel dipilih dengan menggunakan teknik purposive sampling, dengan kriteriakriteria yang telah ditetapkan sebagai berikut:

a. Perusahaan Go Public Sub Sektor Makanan dan Minuman yang terdaftar di Bursa Efek Indonesia tahun 2015-2018.

b. Perusahaan Go Public Sub Sektor Makanan dan Minuman yang menerbitkan laporan keuangan dan laporan tahunan selama tahun pengamatan secara berturut-turut yaitu dari tahun 2015-2018.

c. Perusahaan Go Public Sub Sektor Makanan dan Minuman yang tidak memperoleh laba negatif selama tahun pengamatan 2015-2018.

Sehingga berdasarkan kriteria-kriteria diatas maka jumlah sampel yang didapatkan dalam penelitian ini sebanyak 40 laporan keuangan dari 10 perusahaan selama 4 tahun berturut-turut dari periode 2015-2018.

\section{Jenis dan Sumber Data}

Dalam melaksanakan penelitian ini, jenis data yang di pergunakan adalah data kuantitatif, dikatakan kuantitatif karena data banyak menggunakan angka mulai dari pengumpulan data, penafsiran terhadap data serta penampilan dan hasilnya (Arikunto, 2002 ; dalam Sinolla, 2011). Sumber data dalam penelitian ini adalah data sekunder, dimana diperoleh dari laporan keuangan publikasi yang di terbitkan oleh bursa efek Indonesia melalui IDX (Indonesian Stock Exchange). Periodesasi data menggunakan data laporan keuangan publikasi perusahaan Makanan dan Minuman periode 2015-2018.

\section{HASIL PENELITIAN DAN PEMBAHASAN}

\section{Analisis Regresi Linear Berganda}

Tabel 2. Hasil Analisis Regresi Linear Berganda

\begin{tabular}{|c|c|c|c|c|c|}
\hline \multirow{4}{*}{ Model } & \multicolumn{3}{|c|}{ Coefficients $^{a}$} & \multirow{4}{*}{$\mathrm{T}$} & \multirow{4}{*}{ Sig. } \\
\hline & \multirow{2}{*}{\multicolumn{2}{|c|}{$\begin{array}{c}\text { Unstandardized } \\
\text { Coefficients }\end{array}$}} & \multirow{2}{*}{$\begin{array}{c}\text { Standardized } \\
\text { Coefficients }\end{array}$} & & \\
\hline & & & & & \\
\hline & B & $\begin{array}{l}\text { Std. } \\
\text { Error }\end{array}$ & Beta & & \\
\hline (Constant) & 181.635 & 35.826 & & 5.070 & .000 \\
\hline DOL & 1.445 & .549 & .416 & 2.630 & .013 \\
\hline
\end{tabular}




$$
\begin{array}{llllll}
\text { DFL } & -72.176 & 38.152 & -.300 & { }_{1.89}^{-} & .067
\end{array}
$$

a. Dependent Variable: EPS

Sumber : Hasil ollah data SPSS 22. 2020

Dari tabel tersebut di atas diketahui persamaan regresi berganda adalah sebagai berikut :

a. Variabel leverage operasi dan leverage keuangan konstanta 181.635, menunjukkan bahwa jika sama dengan nol, maka laba per lembar saham akan mengalami peningkatan sebesar 181.635.

b. Variabel leverage operasi (DOL) X1 memiliki koefisien regresi positif sebesar 0.416 yang berarti bahwa apabila variabel leverage operasi naik $1 \%$, maka laba per lembr saham akan mengalami peningkatan sebesar 0.416 , dengan syarat nilainya tetap (konstant).

c. Variabel leverage keuangan (DFL) X2 memiliki koefisien regresi negatif sebesar -0.300 berarti bahwa apabila variabel leverage keuangan meningkat $1 \%$, maka laba per lembar saham akan mengalami penurunan sebesar 0.300 ,dengan syarat nilainya tetap (konstant).

Berikut ini pengujian hipotesis secara parsial sebagai berikut :

a. Pengujian hipotesis pertama (X1)

Diketahui nilai signifikan leverage operasi (DOL) terhadap laba per lembar saham memiliki tingkat signifikan sebesar $0.013<0.05$ dan nilai $t$ hitung 2.630, yang artinya leverage operasi berpengaruh positif dan signifikan terhadap laba per lembar saham.

b. Pengujian hipotesis kedua (X2)

Diketahui nilai signifikan leverage keuangan (DFL) terhadap laba per lembar saham memiliki tingkat signifikan sebesar $0.067>0.05$, dan nilai $t$ hitung sebesar -1.890 artinya leverage keuangan (DFL) berpengaruh negative dan tidak signifikan terhadap laba per lembar saham.

Uji Determinasi $\left(\mathbf{R}^{2}\right)$

Tabel 3. Hasil Uji Determinasi $\left(\mathbf{R}^{2}\right)$

\begin{tabular}{|l|l|l|l|l|}
\hline \multicolumn{5}{|c|}{ Model Summary } \\
\hline Model & R & R Square & $\begin{array}{c}\text { Adjusted R } \\
\text { Square }\end{array}$ & Std. Error of the Estimate \\
\hline
\end{tabular}




\begin{tabular}{|l|r|r|r|r|}
\hline 1 & $.458^{\mathrm{a}}$ & .210 & .162 & 173.06044 \\
\hline a. Predictors: (Constant), DFL, DOL \\
\hline
\end{tabular}

Berdasarkan tabel 3 diatas menunjukkan bahwa uji kofisien determinasi (R2) nilai $R$ Square sebesar 0.210 atau $21 \%$ yang berarti bahwa hubungan antar variabel independen yaitu DOL dan DFL terhadap harga saham memiliki hubungan yang dalam kategori cukup rendah. Hal ini mengartikan bahwa laba per lembar saham (Y) dapat dijelaskan oleh DOL (X1) dan DFL (X2) sedangkan selebihnya dijelaskan oleh faktor-faktor lain yang mempengaruhi laba per lembar saham yang berada diluar model penelitian.

\section{Pembahasan}

Berdasarkan pengujian yang telah dilakukan dengan menggunakan teknik analisis regresi linear berganda, maka diperoleh hasil sebagai berikut:

a. Pengaruh Leverage Operasi terhadap Laba Per Lembar Saham

Hasil analisis untuk variabel Leverage Operasi diketahui bahwa nilai koefisien X1 bernilai positif (1.445) dengan nilai signifikansinya $0.013<0.05$ sehingga hal ini berarti bahwa leverage operasi berpengaruh positif dan signifikan terhadap laba per lembar saham dan hipotesis pertama diterima. Artinya apabila terjadi peningkatan atau penurunan pada leverage operasi (DOL) akan mempengaruhi pendapatan sehingga laba per lembar saham (EPS) yang diberikan kepada pemegang saham juga berpengaruh.

Penjualan yang semakin meningkat akan mampu membiayai biaya tetap perusahaan sebagai akibat penggunaan biaya tetap dalam sebuah kegiatan operasionalnya. Besar kecilnya yang peroleh dalam penjualan akan memperoleh tingkat keuntungan yang akan mempengaruhi laba sebelum pajak. Hasil penelitian ini sejalan dengan penelitian yang dilakukan oleh Fahmi (2014). Yang menunjukkan bahwa secara parsial operating leverage berpengaruh signifikan terhadap Earning Per Share (EPS). Hasil ini sejalan dengan teori yang ada bahwa, operating leverage yang timbul akibat penggunaan asset yang menimbulkan biaya tetap operasional dengan harapan dapat meningkatkan volume penjualan.

b. Pengaruh Leverage Keuangan terhadap Laba Per Lembar Saham

Hasil dari analisis untuk variabel Leverage Keuangan diketahui bahwa nillai koefisien X2 bernilai negatif (-72.176) dengan nilai signifikansinya 0.067 
> 0.05 sehingga dapat disimpulkan bahwa leverage keuangan berpengaruh negatif dan tidak signifikan terhadap laba per lembar saham dan hipotesis kedua ditolak.

Pengaruh negatif pada nilai koefisien artinya, semakin meningkatnya leverage keuangan suatu perusahaan, maka semakin rendah pula nilai laba per lembar saham yang dimiliki perusahaan. Sedangakan leverage keuangan tidak berpengaruh signifikan artinya, besar kecilnya suatu leverage keuangan suatu perusahaan tidak mampu menjelaskan dan memprediksi peningkatan laba per lembar saham.

Penelitian ini sejalan dengan penelitian yang dilakukan oleh Muhammad Hidayat, dkk (2019) yang menyatakan DFL (Deegre Of Financial Leverage) tidak memiliki pengaruh signifikan dan memiliki arah negatif terhadap EPS (Earning Per Share). Hasil penelitian ini menunjukan bahwa teori yang mengatakan Leverage Keuangan dikatakan merugikan, dikarenakan perusahaan tidak dapat memperoleh pendapatan yang lebih besar dan perusahaan mengalami gagal bayar, hal ini menyebabkan perusahaan tidak dapat meningkatkan profitabilitasnya

\section{KESIMPULAN}

Berdasarkan hasil penelitian dan pembahasan, maka dapat disimpulkan bahwa :

1. Hasil pengujian secara parsial leverage operasi terhadap laba per lembar saham berpengaruh secara positif dan dengan nilai $t_{\text {hitung }}$ lebih besar dari $t_{\text {tabel }}(2.630>-1.690)$ dan nilai signifikansi lebih kecil dari 0,05 $(0,013<0,05)$ hal ini berarti hipotesis pertama diterima. Leverage keuangan terhadap laba per lembar saham berpengaruh secara negatif dan tidak signifikan dengan nilai $t_{\text {hitung }}$ lebih besar dari $t_{\text {tabel }}(-1.892>-1.690)$ dan nilai signifikansi lebih besar dari 0,05 $(0.067>0.05)$ hal ini berarti hipotesis kedua ditolak.

2. Hasil pengujian secara simultan atau uji $F$ nilai $F_{\text {hitung }}>F_{\text {tabel }}(4.389>0.051)$ dengan nilai signifikansi 0.020 lebih kecil dari 0.05 , maka dapat disimpulkan bahwa Ha diterima yang berarti leverage operasi dan leverage keuangan berpengaruh positif dan signifikan secara simultan terhadap laba per lemba saham. 
3. Pada pengujian koefisien determinasi variabel hubungan antar leverage operasi dan leverage keuangan terhadap laba per lembar saham memiliki nilai R-square sebesar 0,210 menunjukkan bahwa pengaruh variabel bebas (independen) terhadap variabel terikat (dependen) sebesar 21\% sedangkan sisanya sebesar $79 \%$ dipengaruhi oleh faktor-faktor lain yang tidak dijeleskan dalam penelitian ini.

Adapun saran-saran yang dapat diberikan berkaitan dengan hasil penelitian ini antara lain:

1. Bagi Investor

Pihak manajemen perusahaan disarankan perusahaan yang menggunakan hutang sebagai salah satu sumbernya, sebaiknya proporsi hutang tersebut didasarkan pada perhitungan yang tepat agar pada akhirnya penggunaan hutang tersebut akan mendatangkan keuntungan bagi perusahaan bukan sebaliknya. Jika penggunaan leverage operasi dan leverage keuangan menguntungkan bagi perusahaan maka pendapatan akan lebih besar daripada beban bunganya yang harus dibayar, hal ini akan meningkatkan laba bagi pemegang saham atas modal yang telah ditanamkannya.

2. Bagi Peneliti Selanjutnya

Demi keakuratan hasil penelitian selanjutnya, hendaknya menambah jangka waktu pengamatan yang lebih panjang karena semakin lama waktu pengamatan maka semakin besar kesempatan untuk melakukan pengamatan yang akurat. Serta variabel yang digunakan dalam penelitian ini mungkin belum dapat sepenuhnya memiliki pengaruh terhadap Earnings Per Share (EPS) dalam suatu perusahaan sub sektor makanan dan minuman, maka disarankan bagi peneliti selanjutnya untuk menambah variabel independen atau mengganti variabel independen yang tidak signifikan dalam penelitian ini dengan variabel lain,

\section{DAFTAR PUSTAKA}

Agus Sartono. 2010. Manajemen Keuangan Teori dan Aplikasi. Edisi 4. Yogjakarta: BPFE

Annisa Sulistyo Rini. 2018. Industri Makanan dan Minuman Jadi Andalan Pacu Ekonomi. ( https://ekonomibisnis.com). Diakses pada 13 Agustus 2018. 
Arikunto, Suharsimi, 2010. Prosedur Penelitian Suatu pendekatan Praktek. Jakarta: Rineka Cipta.

Aulia Rakhman (2017). "Pengaruh Financial Leverage dan Operating Leverage Terhadap earnings Per Share pada Perusahaan Sektor Property dan Real Estate Yang Terdaftar Di Bursa Efek Indonesia". Universitas Negeri Yogyakarta. Yogyakarta.

Brigham \& Houston. 2014. Dasar-Dasar Manajemen Keuangan. Jakarta: Salemba Empat.

Chelmi. (2012). Pengaruh Debt to Total Assets Ratio (DAR), Debt to Equity Ratio (DER) dan Long Term Debt to Equity Ratio (LDER) terhadap Earnings Per Share (EPS) pada perusahaan property and real estate di Bursa Efek Indonesia periode 2008-2011.

Darmadji Tjiptono dan Fakhruddin. 2012. Pasar Modal Di Indonesia. Edisi Ketiga. Jakarta : Salemba Empat.

Dewi Utari, Ari Purwanti dan Darsono Prawironegoro, 2014. Manajemen Keuangan Edisi Revisi. Jakarta : Mitra Wacana Media.

Fahmi, Irham. 2013. "Pengantar Manajemen Keuangan”. Bandung : Alfabeta.

Fahmi, Raden Mohammad. 2014. Pengaruh Financial Leverage, Operating leverage, dan Total Aset Turn Over Terhadap Earning Per Share. Jurnal.um.palembang.ac.id

Fajar Budiyanto (2017). "Pengaruh Leverage Operasi dan Leverage Keuangan Terhadap Laba Per Lembar Saham pada Industri Manufaktur Yang Tercatat Di Bursa Efek Indonesia”. Universitas Negeri Yogyakarta. Yogyakarta.

Ghozali, Imam. (2011). Aplikasi Analisis Multivariate Dengan Program IMB SPSS (edisi kelima). Semarang: Universitas Diponegoro.

Harahap, Sofyan Syafri. 2015. Analisis Kritis atas Laporan Keuangan. Edisi 110. Jakarta: Rajawali Pers.

Horne, James C Van dan Jhon M Wachowicz, Jr. 2012. Prinsip-prinsip Manajemen Keuangan (Edisi 13). Jakarta : Salemba Empat.

Sutrisno. 2012. Manajemen Keuangan Teori, Konsep dan Aplikasi (8th ed.). Yogyakarta: Ekonisia.

Kamaludin. 2011. Manajemen Resiko. From (www.pengertianmanagement.blogspot.com) . 22 Mei 2011.

Kasmir. 2013. Analisis Laporan Keuangan. Rajawali Pers : Jakarta.

Kumalasari, Rosita dan Widyawati Nurul. 2016. Pengaruh Operating Leverage dan Financial Leverage Terhadap Profitabilitas Perusahaan 
Telekomunikasi. Sekolah Tinggi IImu Ekonomi Indonesia (STIESIA) Surabaya: Jurnal IImu dan Riset Manajemen. Vol. 5, No. 5, ISSN: 2461-0593.

Keown, A. J., Martin, J. D., Pretty, J. W., \& Scott, D. F. 2010. Manajemen Keuangan Prinsip dan Penerapan. Edisi Kesepuluh. Jilid 2.

Dialihbahasakan oleh Marcus Prihminto Widodo. Jakarta: PT INDEKS.

Madjid, Astriana dan Ida. 2010. Analisa Hubungan Antara Leverage, EPS dan DPS Pada Sektor Retail Trade Yang Terdaftar Di Bursa Efek Indonesia Selama Periode 2003-2006. Jurnal Bisnis dan Ekonomi Hal.. $121-131$.

Margaretha, Farah. 2014. Dasar-dasar Manajemen Keuangan. Jakarta: PT Dian Rakyat.

Mudrajad Kuncoro, (2013). "Metode Riset untukBisnis dan Ekonomi” Edisi 4. Jakarta: Erlangga

Muhammad Hidayat, Muhtar Galib (2019). "Analisis Leverage Operasi Dan Leverage Keuangan Terhadap Earnings Per Share di Perusahaan Industri Pabrik Kertas Yang Terdaftar di Bursa Efek Indonesia”. Journal of Economic, Management, Accounting and Technology (JEMATech). Eksistansi (ISSN 2622-8122), Vol. 2, No. 2, Februari 2019.

Munawir, S. 2010. Analisis laporan Keuangan Edisi keempat. Cetakan Kelima Belas. Yogyakarta: Liberty.

Oktaviano DB Hana. 2019. Produksi Meningkat, Industri Mamin Bakal Menggeliat Tahun Depan. ( https://ekonomibisnis.com). Diakses pada 13 November 2019.

Putra. (2013). Analisis Pengaruh Operating Leverage dan Financial Leverage Terhadap Earnings Per Share di Perusahaan Properti Yang Terdaftar di BEI (2007-2011). Jurnal Manajemen. Universitas Negeri Surabaya Surabaya.

Rifa Afriana Ningtyas, Ronny Malavia Mardani, M. Agus Salim (2018). "Pengaruh Leverage Operasi Dan Leverage Keuangan Terhadap Laba Per Lembar Saham". Jurnal Riset Manajemen. Fakultas Ekonomi Unisma.

Sugiyono. (2013). Metode Penelitian Kuantitatif, Kualitatif dan R\&D. Bandung: Alfabeta.CV

Sugiyono. (2014). Metode Penelitian Pendidikan Pendekatan Kuantitatif, Kualitatif, dan R\&D. Bandung: Alfabeta.

Sugiyono. (2017). Metode Penelitian Kuantitatif, Kualitatif, dan R\&D. Bandung: Alfabeta. 
Sumantri, Bagja. 2014. Pengaruh Kualitas Pelayanan Dan Produk Pembiayaan Terhadap Minat Dan Keputusan Menjadi Nasabah Di Bank Syariah Vol 10 ,No.2, ISSN 2460-115. Yogyakarta, Jurnal Ekonomi dan Bisnis: http://journal.uny.ac.id/index.php/economia/article/view/7540/0

Syamsudin, Lukman, 2011, Manajemen Keuangan Perusahaan, Edisi Baru, Jakarta: PT. Raja Grafindo Persada.

Syamsudin, Lukman. 2013. Manajemen Keuangan Perusahaan. PT. Gramedia Pustaka Utama. Jakarta.

Uci Pratiwi. 2019. Pengaruh Leverage Terhadap Laba Per Lembar Saham pada Perusahaan Manufaktur. Sekolah Tinggi Ilmu Ekonomi Makassar Bongaya. Makassar. 